\title{
INVESTORS' BEHAVIOUR TOWARDS INDIAN MUTUAL FUNDS INVESTMENT
}

\author{
Dr. Parul Mittal \\ Assistant Professor, Department of Commerce, \\ KLP College, Rewari-123401, Haryana, India
}

\begin{abstract}
Purpose: India is experiencing a phase of savings and investment, especially with the growth spurt in its working class. The Indian mutual fund industry is growing rapidly and this is reflected in the increase in Assets under management of various fund houses. This research paper focused on number of factors that highlights investors' behaviour towards mutual funds and preferences of investors. The impact of various demographic and behavioural factors on investors has been studied.

Design/Methodology/Approach: The study is empirical and analytical based on survey approach. It is primary data based study. Data is collected through structured questionnaire. For this purpose, we have used frequency distribution, percentages, chi square test, ANOVA, Average Score analysis and Kruskal Wallis test to prove the hypotheses. Also, Cronbach's Alpha (CFA) is applied to measure the internal consistency of the variables.
\end{abstract}

Findings: The major findings of the study reveal that demographic factors have impact on the investment decisions taken by investors. Also, it is found the aged and educated people preferred mostly safe and high return on their investment. They avoid risk. The study will be beneficial for researchers \& academicians for further research, brokers, dealers, investors and share market officials.

Research Applications/Limitations: this study is helpful to identify the behaviour of investors towards mutual funds investment. Despite at most care, there has been some limitation in this study which may have impact on findings of the study. As we used convenience sampling method and only 100 samples of respondents has been selected, it is difficult to generalize the findings to the large population. We have selected a limited area i.e. only Delhi and NCR. Also, there may be errors in development of questionnaire and data feeding.

Practical Implications: Contributes to the body of knowledge on investor's behaviours, perception $n$ their attitude towards investment in mutual funds and its implications for investors, agencies and government for formulating policies.

Originality/Value: The paper identifies a framework of relevant values and facilities that will be of use to those interested in this field. 
Key words: Mutual Funds, Investors' behaviour, risk \& returns, perception and attitude

Cite this Article: Parul Mittal, Investors' Behaviour towards Indian Mutual Funds Investment, International Journal of Management, 11(12), 2020, pp 1773-1785.

http://iaeme.com/Home/issue/IJM?Volume $=11 \&$ Issue $=12$

\section{INTRODUCTION}

A wide array of investment instruments is available to an investor like non-marketable financial assets, equity shares, money market instruments, debt instruments, bonds, precious commodities, mutual funds, life insurance, financial derivatives, real estate etc. With reforms in financial sector and the developments in the Indian financial markets, Mutual Funds (MFs) have emerged to be an important investment avenue for retail (small) investors. For all investors, particularly the small investors, mutual funds have provided a better alternative to obtain benefits of expertise- based equity investments to all types of investors. A Mutual fund is a trust that pools the savings of a number of investors' who share a common financial goal. The money collected from investors' is invested in capital market instrument such as shares, debentures and other securities. The income earned through these investments and the capital appreciations realized are shared by its unit's holder in proportion to the number of units owned by them. Thus a Mutual Fund is the most suitable investment to the common man as it offers an opportunity, to invest in a diversified, professionally managed basket of securities at relatively low cost. A mutual fund is an investment company that creates a bridge between individual investors or retail investors \& corporate giants. Mutual funds provide an investment options for retail investors or individual investors those who are not aware about stock market still they want to invest their funds in stock market with a small amount of money. A mutual fund is a pure intermediary which performs basic function of buying \& selling security on behalf of its investors or unit holders. Mutual funds mobilize saving from a large number of investors $\&$ invest these funds in shares and other securities.

Mutual Funds are sine qua non for the development of the capital markets \& the creation of the equity cult in an economy. The inception of Unit Trust of India marked the evolution of the Indian mutual fund industry in the year 1963. The basic objective at that time was to attract the small investors or retail investors for investment and it was made possible through the collective efforts of the Government of India and the Reserve Bank of India. The history of mutual fund industry in India can be better understood divided into following stages:

Stage I. Establishment and Growth of Unit Trust of India - 1964-87

Stage II. Entry of Public Sector Funds - 1987-1993

Stage III. Emergence of Private Sector Funds - 1993-96

Stage IV. Growth and SEBI Regulation - 1996-2004

Stage V. Growth and Consolidation - 2004 Onwards

A mutual is a set up in the form of trust, which has sponsor, trustee, assets management company (AMC) and custodian. Sponsor is the person who acts alone or in combination with another body corporate and establishes a mutual fund. Sponsor must contribute at least $40 \%$ of the net worth of the investment managed and meet the eligibility criteria prescribed under the Securities and Exchange Board of India (Mutual Funds) regulations, 1996. The Mutual Fund is constituted as a trust in accordance with the provisions of the Indian Trusts Act, 1882 by the Sponsor. Trustee is usually a company (corporate body) or a board of trustees (body of individuals). The main responsibility of the trustee is to safeguard the interest of the unit holders and also ensure that AMC functions in the interest of investors' and in accordance with the Securities and Exchange Board of India (Mutual Fund) Regulations 1996 the 
provisions of the Trust deed and the offer Document of the respective schemes. The AMC is appointed by and updates investor records. Industry AUM still far behind Rs. 97 trillion aggregate the Trustees as the investment Manager of the Mutual Fund. The AMC is required to be approved by SEBI to act as an asset management company of the Mutual Fund. The AMC if so authorized by the Trust Deed appoints the Registrar and Transfer Agent to agent the mutual fund. The asset management industry in India is among the fastest growing in the world. As of November 2017, 42 asset management companies were operating in the country. India registered a record inflow of amount of US\$ 51.02 billion in mutual funds in FY 201617. According to the Association of Mutual Funds in India (AMFI) data, this was the highest investment in mutual fund schemes since the fiscal 1999-2000. Inflows in India's mutual fund schemes via the systematic investment plan (SIP) route reached Rs 536 billion (US\$ 8.34 billion) between April-January 2018 (Figure 1).

Mutual Funds can be invested in many different kinds of securities. The most common are cash, stock, and bonds, but there are hundreds of sub-categories. Stock funds invest primarily in the shares of a particular industry, such as technology or utilities. These are known as sector funds. Bond funds can vary according to risk (e.g., high-yield or junk bonds, investment-grade corporate bonds), type of issuers (e.g., government agencies, corporations, or municipalities), or maturity of the bonds (short- or long-term). Both stock and bond funds can invest in primarily U.S. securities (domestic funds), both U.S. and foreign securities (global funds), or primarily foreign securities (international funds).

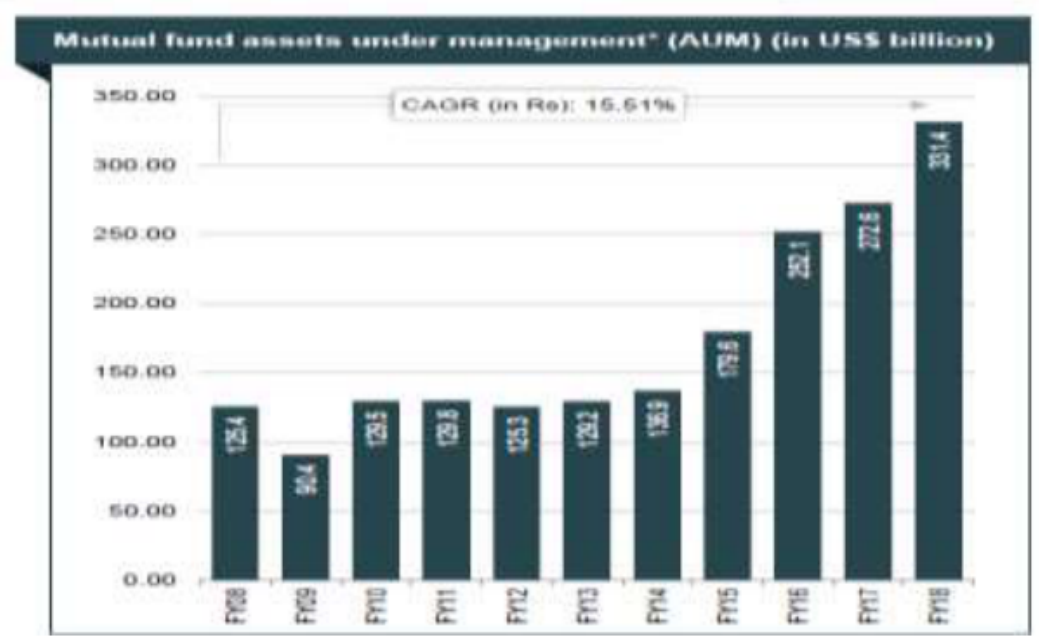

Figure 1 Progress of Mutual Fund Industry

Note: AUM - Assets Under Management, * - as on the March 31st of every year, *- Exchange rate used is average of 2017-18 i.e. 64.45

Source: AMFI, Aranca Research

\section{LITERATURE REVIEW}

Ippolito (1992) states that an investor is ready to invest in those funds or schemes which have resulted in good rewards and most investors' are attracted by those funds or schemes that are performing better over the worst. Goetzman (1997) opined that investor's psychology affects mutual fund selection for investment and to withdraw from the fund. Sahadevan and Thiripalraju (1997) analyzed the performance of private sector funds they compiled and analyzed the monthly average return and standard deviation of 10 selected private sector funds. The investigation reveals that in terms of the rate of return, 5 funds viz., Alliance 95, ICICI Power, Kothari Prima, Kothari Pioneer Blue Chip and Morgan Stanley Growth Fund 
outperformed the market, during the period of comparison. The analysis also shows that, by and large, performance of a fund is not closely associated with its size. Gupta \& Sehgal (1998) tried to find out the investment performance of 80 schemes managed by 25 mutual funds, 15 in private sector and 10 in public sector for the time period of June 1992-1996. The study has examined the performance in terms of fund diversification and consistency of performance. The paper concludes that mutual fund industry's portfolio diversification has performed well. But it supported the consistency of performance. Shanmugham (2000) conducted a survey of individual investors with the objective to find out what information source investor depends on. The results explained that they are economical, sociological and psychological factors which control investment decisions. Singh and Jha (2009) conducted a study on awareness $\&$ acceptability of mutual funds and found that consumers basically prefer mutual fund due to return potential, liquidity and safety and they were not totally aware about the systematic investment plan. The invertors' will also consider various factors before investing in mutual fund. Chandra \& Kumar (2012) concluded that investor behavior is influenced by a variety of psychological heuristics and biases by documenting survey data from 350 individual investors. Their findings underline an asymmetric pattern of information distribution and usage among investors which impacts their investment behavior to a large extent. Sireesha \& Laxmi (2013) researched the impact of demographics on the investment avenues that are selected by investors in the cities of Hyderabad and Secunderabad. They found that gender, age, and peer group influence the investment decision and also investors are less concerned about money multiplication and liquidity but want their money to be secure and risk free. Velmurugan et. al. (2015) studied the perception of investors towards investment in mutual funds in Vellore city of Tamil Nadu. They found that aged and high income investors prefer to invest in post office and bank savings due to safety purpose. They further observed that male perception towards various investment avenues is more or less equal with female investors. Lastly, it was found that the order of preference on investment towards real estate and insurance are same cross the age group though it varies with regard o stock market, gold, bank savings and post office. Raman \& Budhiraja (2015) identified the pattern of investment of retail investors with special emphasis on mutual fund industry. They found that for almost all the age groups, the rate of return associated with the investment option is the most important factor in consideration. Study showed that age groups and risk appetite are associated with each other while there is no association between the risk appetite of investors and their level of education. Lastly, the gender of investor does not impact the influence of other factors while investing and there is no significant difference in their influence between different classes of investors. Baral (2016) studied the evolution of mutual funds in India and analyzed the growth trend of the mutual funds industry. Mutual Funds have emerged as an important financial intermediary globally, particularly in India where retail investors represent $97.7 \%$ of the 4.70 crores investor accounts. Virk \& Singh (2017) highlighted the current scenario of Indian Mutual Fund Industry and recent development measures given by regulatory authorities. Sanjay \& Raj (2019) tried to study the chronological evaluation of mutual fund industry and growth in AUM, Investor Accounts, Investor wise (Retail \& HNI) growth rate, Scheme wise growth rate in investor accounts. They found that MF Industry is growing in terms of AUM and scheme-wise policy is also increasing but there is negative correlation between equity $\mathrm{n}$ debts.

In this paper, an attempt is made by the author, mainly to study the behavior of investors regarding mutual funds in Delhi and NCR. 


\section{OBJECTIVES OF THE STUDY}

The following objectives are framed to study the investors' behaviour towards various investment avenues.

- To analyze the impact of various demographic factors on investors' attitude towards mutual fund.

- To study the factors which influence investor's behaviour while making investment.

- To find out the perception of investors relating to low risk/safety, liquidity, high returns and reputation of the company dimensions.

- To ascertain the factors influencing the investors towards selection/order of preference of various investment avenues.

\section{TESTING OF HYPOTHESES}

The following null hypotheses have been taken for the study of investors' behavior towards mutual funds.

- Annual income of the investor and amount of investment in mutual fund are Independent of each other.

- Knowledge about mutual fund and the qualification of the investors are independent of each other.

- Factor preferred the most while taking investment decision and age of the investor are independent of each other.

- Occupation of individual investor and the feature that allures him the most are independent of each other.

- There is no significant difference in the perception of investors related to low risk/safety, liquidity, reputation of the company and high returns.

- There is no significant difference in the order of preference of various investment avenues across the age and income level of the respondent.

\section{RESEARCH METHODOLOGY}

The study is empirical and analytical based on survey approach. The design of the study aims to analyze the preferential investment avenue of retail investors and the use of demographical analysis to allocate these preferences through the use of primary data. For this purpose, a diversified sample of 100 educated investors of Delhi and NCR, India in Mutual Funds have been selected by sampling method. All the data required for this analytical study has been obtained mainly from primary sources, but at times, secondary sources of data have also been considered. The secondary data was collected from related research works, published books, journals, and reports of Securities and Exchange Board of India (SEBI), Association of Mutual Fund of India (AMFI), Reserve Bank of India (RBI), website of Mutual Funds of India and other authorized sources of data. The data collection method used to obtain the desired information from primary sources has been through direct interview and structured questionnaire (open and closed ended questions) has been used as an instrument. Part I of questionnaire is related with demographic profile on investors and Part II consists of behavioural aspects of investors. Judgment and convenient sampling has been used for colleting the sample. The reduced set of 9 items was tested for reliability using Cronbach Alpha. The Cronbach Alpha was 0.803 for the 100 sets of responses. This shows a fair degree of internal consistency amongst the items. For analyzing the collected data, a number of statistical techniques basically descriptive statistics (percentages, frequency distribution and 
averages), ANOVA, Chi-square test, Average mean Score and Kruskal Wallis test have been used. Software Package for Social Sciences (SPSS) has been used to analyze the data collected.

\section{DATA ANALYSIS AND INTERPRETATION}

The data collected through the questionnaire is analyzed considering each factor and the analysis is presented below:

\subsection{Demographic Summary of Investors (Percentage Analysis)}

The investment preference of the investor has been classified on the basis of several socioeconomic variables and some selective investment profile factors i.e.

Table 1 Distribution of Sample Data

\begin{tabular}{|l|l|c|c|}
\hline \multicolumn{1}{|c|}{ Variables } & \multicolumn{1}{c|}{ Category } & Frequency & Percentage \\
\hline Gender & Male & 92 & 92 \\
\hline & Female & 8 & 8 \\
\hline Age & Total & 100 & 100 \\
\hline & Less than 30 years & 43 & 27 \\
\hline & $30-40$ & 27 & 19 \\
\hline & $40-50$ & 19 & 11 \\
\hline & More than 50 years & 11 & 100 \\
\hline Occupation & Total & 100 & 18 \\
\hline & Professionals & 18 & 23 \\
\hline & Business & 23 & 57 \\
\hline & Salaried & 57 & 2 \\
\hline & Retired & 2 & 100 \\
\hline Education & Total & 100 & 3 \\
\hline & High School & 3 & 26 \\
\hline & Graduation & 26 & 49 \\
\hline & Post Graduation & 49 & 22 \\
\hline & Professional & 22 & 100 \\
\hline Income Status & Total & 100 & 51 \\
\hline & Less than 5 lakh & 51 & 34 \\
\hline & $5-15$ & 34 & 12 \\
\hline & $15-25$ & 12 & 3 \\
\hline & More than 25 lakh & 3 & 100 \\
\hline
\end{tabular}

Source: Authors' Findings.

From the above table, we see that most of the investors (92\%) were male members and only $8 \%$ were females. It is clear from the above graph that most of the investors belong to the age group of less than 30 years followed by those belonging to the age group of 30 to 40 years. Most of the investors belong to the salaried profile followed by businessmen and others professionals. Most of the respondents were post graduated followed by graduated investors and professional degree holders. The yearly income profile of the investor reflects that $51 \%$ of the investor belongs to the income level of less than Rs 5 Lakh followed by $34 \%$ of the investors belong to the income group of Rs 5-15 Lakh. 


\subsection{Behavioural Analysis}

\subsubsection{Investment Avenue Preferred by the Investor}

Majority of the investors prefer investing in saving accounts $(57 \%)$ followed by mutual funds $(53 \%)$. Only $18 \%$ prefer investment in post office.

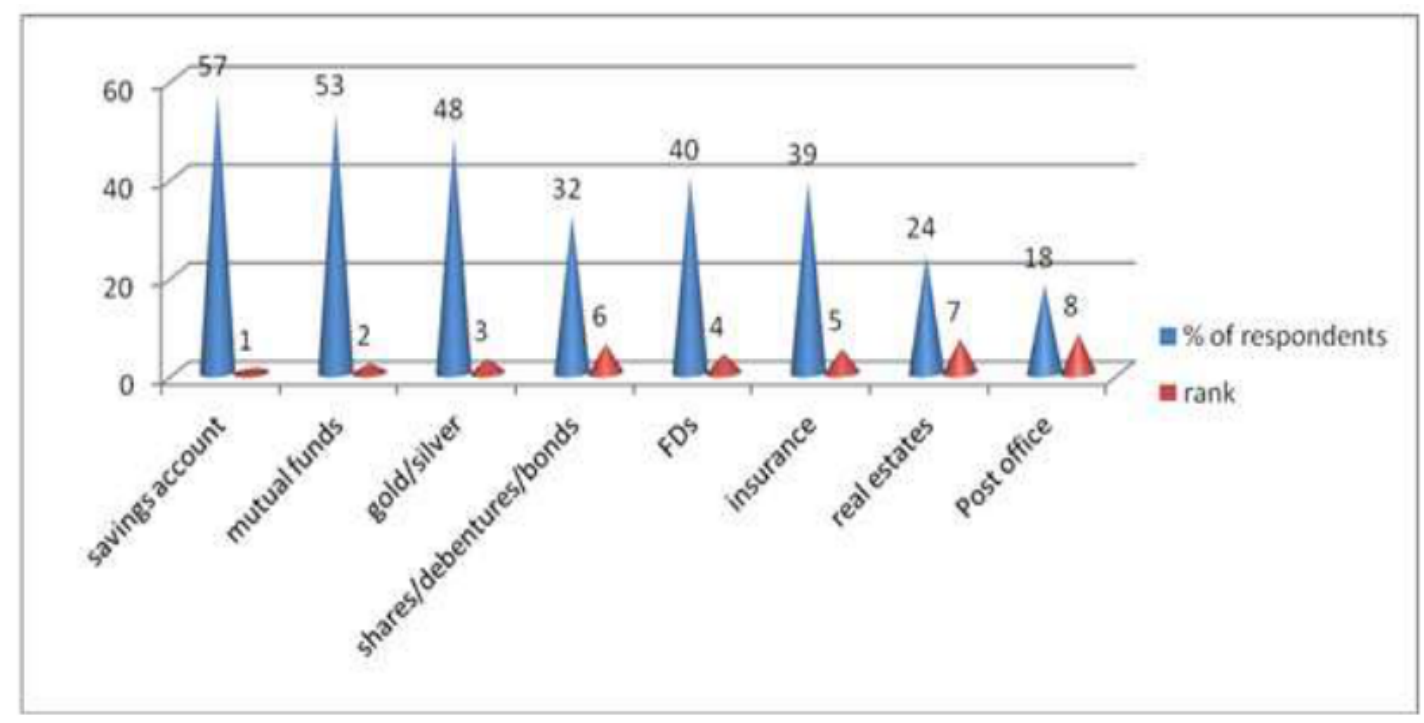

Figure 2 Investment Avenue Preferred by the Investor

\subsubsection{Type of Mutual Fund Scheme Invested}

Near about $32 \%$ of respondents have invested in open ended mutual funds followed by diversified funds, large cap funds, monthly income PI and close ended funds.

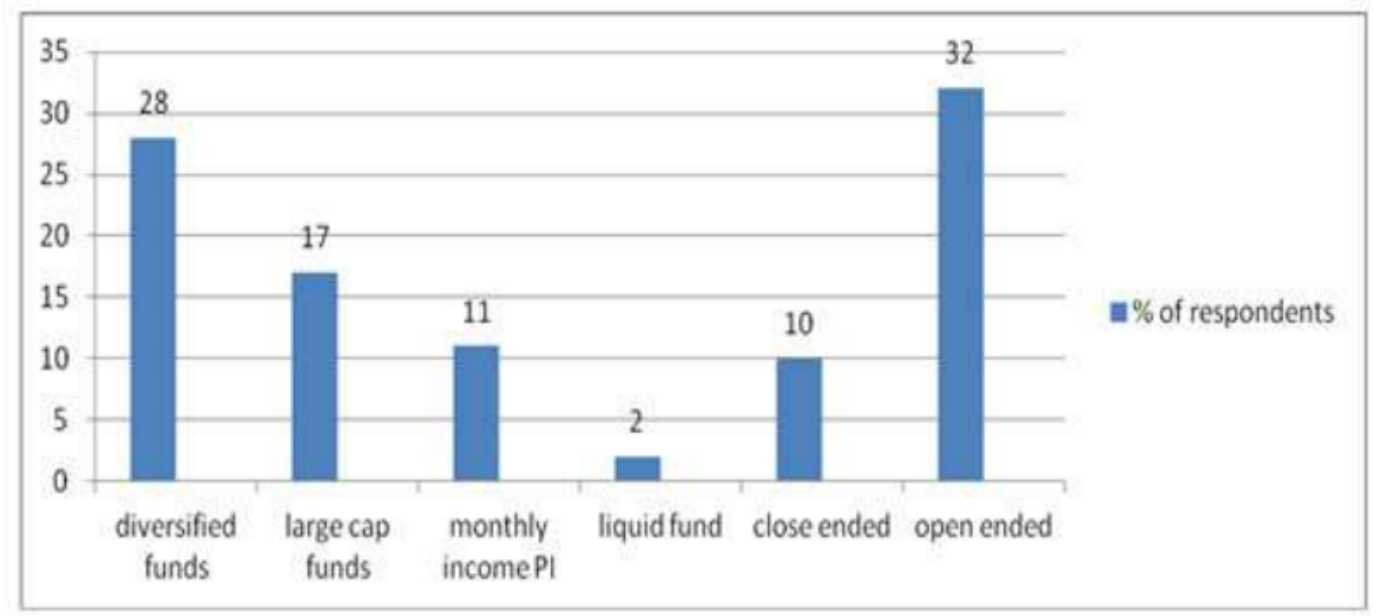

Figure 3 Type of Mutual Fund Scheme Invested

\subsubsection{Preference upon Information Mode}

Only $38 \%$ investors took help of brokers \& agents and $28 \%$ investors invest in mutual funds as per the suggestions and information received from friends and relatives. 


\section{$\%$ of Respondents}

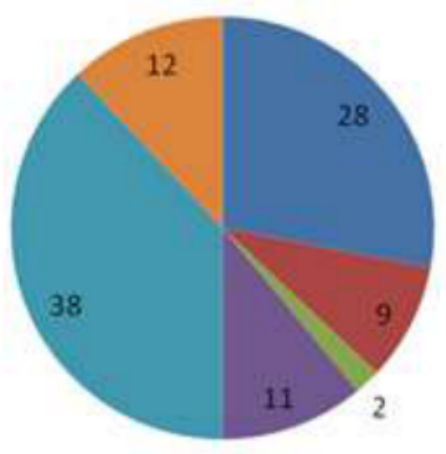

m friends \& relatives

atv/radio

=e-mails

newspapers \& magazines

w brokers \& agents

Eelf deciisons.

Figure 4 Preference upon Information Mode

\subsubsection{Income of Investors and Amount of Investment in Mutual Funds}

Chi square test has been applied to measure the association between income of the investor and amount of investment in mutual fund.

Table 2 Incomes of Investors and Amount of Investment in Mutual Funds

\begin{tabular}{|l|c|c|c|c|}
\hline \multirow{2}{*}{ Annual Income } & \multicolumn{4}{|c|}{ Amount of Investment (in Rs.) } \\
\cline { 2 - 5 } & Less than 50000 & $\mathbf{5 0 0 0 0 - 1 0 0 0 0 0}$ & More than 100000 & Total \\
\hline Less than 5 lakh & 29 & 22 & 0 & 51 \\
\hline 5-15 lakh & 4 & 22 & 8 & 34 \\
\hline 15-25 lakh & 2 & 6 & 4 & 12 \\
\hline More than 25 lakh & 0 & 1 & 2 & 3 \\
\hline Total & 35 & 51 & 14 & 100 \\
\hline
\end{tabular}

Inference: Table 2 reveals that Chi square calculated value is 30.169 and tabulated value for the same is 12.592. As calculated value is less than tabulated value, Ho is rejected. Annual income of the investor and amount of investment in mutual fund are dependent of each other.

\subsubsection{Qualification of Respondents and Knowledge about Mutual Funds}

Chi square test has been applied to measure the relation between knowledge about mutual fund and the qualification of the investors.

Table 3 Qualifications of Respondents and Knowledge about Mutual Funds

\begin{tabular}{|l|c|c|c|c|c|}
\hline \multirow{2}{*}{ Qualification } & \multicolumn{5}{|c|}{ Knowledge about Mutual Funds } \\
\cline { 2 - 6 } & Ignorant & $\begin{array}{c}\text { Partial } \\
\text { Knowledge }\end{array}$ & $\begin{array}{c}\text { Aware of specific } \\
\text { schemes }\end{array}$ & $\begin{array}{c}\text { Fully } \\
\text { Aware }\end{array}$ & Total \\
\hline High School & 0 & 0 & 3 & 0 & 3 \\
\hline Graduation & 3 & 7 & 14 & 2 & 26 \\
\hline Post Graduation & 0 & 29 & 15 & 5 & 49 \\
\hline Professional & 0 & 1 & 18 & 3 & 22 \\
\hline Total & 3 & 37 & 50 & 10 & 100 \\
\hline
\end{tabular}

Inference: The calculated value of $\chi^{2}=288.779$ and tabulated value of $\chi^{2}=16.919$ at $5 \%$ level of significance. We reject the null hypothesis. So, knowledge about mutual fund and the qualification of the investors are dependent of each other. Usually it is referred that the 
qualification of an individual would also affect his knowledge about various avenues for investment.

\subsubsection{Age of Investors and Factors Preferred most while making Investment}

ANOVA test has been used to test the whether there is a relationship between age of investors and factors preferred most while making investment decisions by investors.

Table 4 Factors Preferred the Most by Investors

\begin{tabular}{|l|c|c|c|c|c|}
\hline \multirow{2}{*}{ Age } & \multicolumn{5}{|c|}{ Factors Preferred the Most (in \%) } \\
\cline { 2 - 6 } & Liquidity & High Return & Low Risk & $\begin{array}{c}\text { Reputation of } \\
\text { the Company }\end{array}$ & Total \\
\hline Less than 30 Years & 8 & 21 & 9 & 5 & 43 \\
\hline 30-40 years & 7 & 14 & 5 & 1 & 27 \\
\hline 40-50 years & 5 & 6 & 5 & 3 & 19 \\
\hline 50 Years \& Above & 2 & 3 & 5 & 1 & 11 \\
\hline Total & 22 & 44 & 24 & 10 & 100 \\
\hline
\end{tabular}

ANOVA Table

\begin{tabular}{lcccccc}
\hline \multicolumn{1}{c}{ Source of Variation } & $\boldsymbol{S S}$ & d.f. & $\boldsymbol{M S}$ & $\boldsymbol{F}$ & $\boldsymbol{P}$-value & F critical \\
\hline Rows & 140 & 3 & 46.66667 & 4.117647 & 0.042854 & 3.862548 \\
Columns & 149 & 3 & 49.66667 & 4.382353 & 0.036706 & 3.862548 \\
Error & 102 & 9 & 11.33333 & & & \\
Total & 391 & 15 & & & & \\
\hline
\end{tabular}

Inference: Since, the $p$ value is less than 0.05 ; the null hypothesis is rejected at $5 \%$ level of significance. We reject the null hypothesis. Factors preferred the most while taking investment decisions and age of the investors are dependent of each other.

\subsubsection{Analysis for Investor's Behaviour (Average Score Analysis)}

The factors affecting investment decision has been analyzed with the help of average score analysis. The respondents' age were compared to the factors that played an important role in their investment decision to find the factor that most affects decision making.

Table 5 Mean Score Analysis of Age vs. Factors Influencing Investment in Mutual Funds

\begin{tabular}{|l|c|c|c|c|c|}
\hline \multicolumn{1}{|c|}{ Age Group } & $\begin{array}{c}\text { Rate of } \\
\text { Return }\end{array}$ & $\begin{array}{c}\text { Risk } \\
\text { Involved }\end{array}$ & $\begin{array}{c}\text { Past } \\
\text { Performance }\end{array}$ & $\begin{array}{c}\text { Government } \\
\text { Policy }\end{array}$ & $\begin{array}{c}\text { Initial } \\
\text { Requirement } \\
\text { of Funds }\end{array}$ \\
\hline Less than 30 years & 1.14 & 1.96 & 2.56 & 2.58 & 2.58 \\
\hline $30-40$ & 1.08 & 1.23 & 2.10 & 2.87 & 2.76 \\
\hline $40-50$ & 1.00 & 1.04 & 2.15 & 3.10 & 2.34 \\
\hline More than 50 years & 1.11 & 1.00 & 2.43 & 3.40 & 2.50 \\
\hline Total & 1.15 & 1.65 & 2.34 & 2.78 & 2.60 \\
\hline
\end{tabular}

Inference: Table 5 shows that the most important factor that affects the decision making is rate of return for all age groups' persons. Next, the risk factor affects the decisions taken by investor of all age groups. The person of more than 50 years age group considers mainly risk involved in the investment while making investment decisions. 


\subsubsection{Occupation of Investors and Features that allures Investors the most while making Investment in Mutual Funds}

ANOVA test has been used to test the whether there is a relationship between occupation of investors and features that allures the investors most while investing in Mutual Funds.

Table 6 Features that allures the investors most while investing in Mutual Funds

\begin{tabular}{|l|c|c|c|c|c|c|}
\hline \multirow{3}{*}{ Occupation } & \multicolumn{6}{|c|}{ Features that allures the investors most while investing in Mutual Funds } \\
\cline { 2 - 7 } & $\begin{array}{c}\text { Diversificatio } \\
\text { n }\end{array}$ & $\begin{array}{c}\text { Better } \\
\text { Return \& } \\
\text { Safety }\end{array}$ & $\begin{array}{c}\text { Regular } \\
\text { Income }\end{array}$ & $\begin{array}{c}\text { Tax } \\
\text { Benefits }\end{array}$ & $\begin{array}{c}\text { Reduction in risk } \\
\text { \& Transaction } \\
\text { Cost }\end{array}$ & Total \\
\hline Professionals & 5 & 7 & 1 & 3 & 2 & 18 \\
\hline Businessman & 2 & 13 & 2 & 6 & 0 & 23 \\
\hline Salaried & 7 & 15 & 8 & 24 & 3 & 57 \\
\hline Retired & 0 & 2 & 0 & 0 & 0 & 2 \\
\hline Total & 14 & 37 & 11 & 33 & 5 & 100 \\
\hline
\end{tabular}

ANOVA Table

\begin{tabular}{lcccccc}
\hline Source of Variation & SS & d.f. & $\boldsymbol{M S}$ & $\boldsymbol{F}$ & $\boldsymbol{P}$-value & F critical \\
\hline Rows & 321.2 & 3 & 107.0667 & 6.212766 & 0.008623 & 3.490295 \\
Columns & 200 & 4 & 50 & 2.901354 & 0.038171 & 3.259167 \\
Error & 206.8 & 12 & 17.23333 & & & \\
Total & 728 & 19 & & & & \\
\hline
\end{tabular}

Inference: Since, the $p$ value is less than 0.05 ; the null hypothesis is rejected at $5 \%$ level of significance. Occupation of individual investor and the feature that allures him the most are dependent of each other.

\subsubsection{One Way ANOVA}

ANOVA test has been used to study the difference among various reason for which investors invest their money in different investment avenues. It studied that whether there is no significant difference in the perception of investors related to low risk/safety, liquidity, high returns and reputation of the company. The data pertaining to perception of investors related to safety, liquidity and high returns relating to investment is presented here:

Table 7 One Way ANOVA Table

\begin{tabular}{|l|c|c|c|c|}
\hline \multicolumn{1}{|c|}{ Variables } & Low Risk/Safety & Liquidity & High Returns & $\begin{array}{c}\text { Reputation of } \\
\text { Company }\end{array}$ \\
\hline Mean & 3.65 & 3.30 & 3.56 & 3.25 \\
\hline N & 800 & 800 & 800 & 800 \\
\hline S.D & 1.230 & 1.547 & 1.215 & 1.472 \\
\hline F Value & 3.472 & 2.165 & 0.788 & 2.564 \\
\hline Sig. Value & .003 & .043 & .743 & .067 \\
\hline
\end{tabular}

Source: Author's findings. *Significant at 5\% level.

Inference: The above table indicates that the F-value is $3.472 \& 2.165$ and significance is $0.003 \& 0.043$ at $5 \%$ level. Since the Significance value is less than the $\alpha=0.05$, the mean difference existing only for low risk/safety and Liquidity as an investment reason across various investment avenues are significant at $5 \%$ level. 


\subsubsection{Kruskal Wallis Test}

This test has been used to ascertain that whether there is no significant difference in the order of preference of various investment avenues across the age and income level of the respondent. The data pertaining to age, annual income and investment avenues are given in below table:

Table 8 Age, Annual Income and Investor's Perception towards Investment Avenues

\begin{tabular}{|c|c|c|c|c|c|c|}
\hline $\begin{array}{c}\text { Investment } \\
\text { Avenues }\end{array}$ & Age & $\begin{array}{c}\text { Chi- } \\
\text { Square }\end{array}$ & $\begin{array}{c}\text { Asymp. } \\
\text { sig. }\end{array}$ & Annual Income & $\begin{array}{c}\text { Chi- } \\
\text { Square }\end{array}$ & $\begin{array}{c}\text { Asymp. } \\
\text { sig. }\end{array}$ \\
\hline \multirow{4}{*}{$\begin{array}{l}\text { Saving } \\
\text { account }\end{array}$} & Less than 30 years & \multirow[t]{4}{*}{12.576} & \multirow[t]{4}{*}{$.002^{*}$} & Less than 5 lakh & \multirow[t]{4}{*}{0.832} & \multirow[t]{4}{*}{.628} \\
\hline & $30-40$ & & & $5-15$ & & \\
\hline & $40-50$ & & & $15-25$ & & \\
\hline & More than 50 years & & & More than 25 lakh & & \\
\hline \multirow[t]{4}{*}{ Mutual Funds } & Less than 30 years & \multirow[t]{4}{*}{15.253} & \multirow[t]{4}{*}{$.006^{*}$} & Less than 5 lakh & \multirow[t]{4}{*}{9.192} & \multirow[t]{4}{*}{$.024 *$} \\
\hline & $30-40$ & & & $5-15$ & & \\
\hline & $40-50$ & & & $15-25$ & & \\
\hline & More than 50 years & & & More than 25 lakh & & \\
\hline \multirow{4}{*}{ Gold/Silver } & Less than 30 years & \multirow[t]{4}{*}{13.132} & \multirow[t]{4}{*}{$.000^{*}$} & Less than 5 lakh & \multirow[t]{4}{*}{3.953} & \multirow[t]{4}{*}{.187} \\
\hline & $30-40$ & & & $5-15$ & & \\
\hline & $40-50$ & & & $15-25$ & & \\
\hline & More than 50 years & & & More than 25 lakh & & \\
\hline \multirow[t]{4}{*}{ Stock Market } & Less than 30 years & \multirow[t]{4}{*}{24.297} & \multirow[t]{4}{*}{$.001^{*}$} & Less than 5 lakh & \multirow[t]{4}{*}{2.142} & \multirow[t]{4}{*}{.572} \\
\hline & $30-40$ & & & $5-15$ & & \\
\hline & $40-50$ & & & $15-25$ & & \\
\hline & More than 50 years & & & More than 25 lakh & & \\
\hline \multirow[t]{4}{*}{ FDs } & Less than 30 years & \multirow[t]{4}{*}{3.872} & \multirow[t]{4}{*}{.127} & Less than 5 lakh & \multirow[t]{4}{*}{2.925} & \multirow[t]{4}{*}{.403} \\
\hline & $30-40$ & & & $5-15$ & & \\
\hline & $40-50$ & & & $15-25$ & & \\
\hline & More than 50 years & & & More than 25 lakh & & \\
\hline \multirow[t]{4}{*}{ Insurance } & Less than 30 years & \multirow[t]{4}{*}{6.825} & \multirow[t]{4}{*}{.084} & Less than 5 lakh & \multirow[t]{4}{*}{6.146} & .068 \\
\hline & $30-40$ & & & $5-15$ & & \\
\hline & $40-50$ & & & $15-25$ & & \\
\hline & More than 50 years & & & More than 25 lakh & & \\
\hline Real Estates & Less than 30 years & 3.928 & .143 & Less than 5 lakh & 2.057 & .316 \\
\hline & $30-40$ & & & $5-15$ & & \\
\hline & $40-50$ & & & $15-25$ & & \\
\hline & More than 50 years & & & More than 25 lakh & & \\
\hline Post Office & Less than 30 years & 11.273 & $.003 *$ & Less than 5 lakh & 8.268 & $.016^{*}$ \\
\hline & $30-40$ & & & $5-15$ & & \\
\hline & $40-50$ & & & $15-25$ & & \\
\hline & More than 50 years & & & More than 25 lakh & & \\
\hline
\end{tabular}

Source: Author's findings. *Significant at 5\% level.

Inference: Table deciphers that age and investment avenues are significantly associated with each other. The calculated values of Kruskal Wallis test in all variables like saving account (0.002), mutual funds (0.006), gold/silver (0.000), stock market (0.001) and post office $(0.003)$ are less than the hypothetical value $(\alpha=0.05)$ at $5 \%$ level of significance except the variables like FDs, real estates and insurance. Hence, null hypothesis is rejected. Therefore, there is significant relation between age and behaviour of investors towards different investment avenues.

Further, we have also applied the same test for examining the relation between income status and investors' perception towards different investment avenues. The calculated value of variables like mutual funds and post office are less than the hypothetical value $(\alpha=0.05)$ at $5 \%$ significance level. Hence, null hypothesis is rejected. Therefore, it is clear that there is 
association between the income status of investors and their perception under some variables. So, the order perception on investment towards mutual funds and post office are same across the income level however it is different in saving account, stock market, insurance, FDs, gold/silver and real estates.

\section{FINDINGS OF THE STUDY}

The findings of the study indicate that as far as factors responsible for investing in mutual funds is concerned, return potential and liquidity have been remains priority. Most of the investors belong to the salaried profile followed by businessmen and others professionals. Majority of the investors prefer investing in saving accounts $(57 \%)$ followed by mutual funds $(53 \%)$. Majority of the investors have moderate risk capacity while those falling into the low risk category fall close second. Only 38\% investors took help of brokers \& agents and $28 \%$ investors invest in mutual funds as per the suggestions and information received from friends and relatives. Factors preferred the most while taking investment decisions and age of the investors are dependent of each other and the knowledge about mutual fund and the qualification of the investors are dependent of each other.

\section{SUGGESTIONS}

There are some suggestions for better investing for investors that they should keep their investment for long time keeping in mind the level of risk involve and saving pattern, they should take help of private financial consultants' to have investment portfolio so as to reduce risk in investment, they should not invest in high volatile funds, they should collect all possible information before investment, periodical review should be done for investment and risk analysis should be done regularly and properly, maintain proper records for each transaction. A careful and reasonable diversification of investment in mutual fund should also be there on investor's part to balance the risk involved in investment. It is also suggested that investor should have a habit of regular saving to earn some more extra consistently through changing market scenario since small savings will grow into bigger capital base. One of the strong suggestions is that to invest a reasonable part of investment in to liquid security so that to meet any contingency.

\section{CONCLUSION}

The study has brought to light the differences in the patterns of investment among various classes of investors based on demographical differences. The study conducted shows that the investors are aware of various schemes of mutual funds. Better return \& safety and tax benefit is the main factors of mutual fund that allure the investors. The mutual fund industry in the country has a lot to explore and look forward to. Despite the challenges it faces in terms of lack of awareness and low financial literacy, there is a growing importance of the industry with the increase in the youth population and the working class of the country.

\section{REFERENCES}

[1] Chandra, A., \& Kumar, R. (2012), "Factors Influencing Indian Individual Investor Behavior: Survey Evidence", Decision, XXXIX (3), 143-167.

[2] Das, D. B., Mohanty, S., \& Shil, N. C. (2008). Mutual Fund vs. Life nsurance: Behavioral Analysis of Retail Investors. International Journal of Business and Management, III (10), 89103.

[3] http://rbi.org.in

[4] http://www.amfiindia.com 
[5] http://www.mutualfundsindia.com

[6] Kumar, A., \& M.C. Lee, C. (2006). Retail Investor Sentiment and Return Comovements. The Journal of Finance, LXI (5), 2451-2486.

[7] Mehra, G., \& Kalia, A. (2013). Indian Mutual Fund Industry: Unearthing the Growth Potential in Untapped Markets. Mumbai: Confederation of Indian Industry and PwC.

[8] Mehta \& Shah (2012), "Preference of Investors for Indian Mutual Funds and its Performance Evaluation”, Pacific Business Review International, Volume 5, Issue 3, pp. 62-76.

[9] Paul, T., \& Bajaj, S. (2012). Influence of Demographic Profile of Equity Investors on Their Level of Awareness about Equity Market. The International Journal of Management, I (4), 112.Unedited version. Copyright by Author(s) 13

[10] Praba, R. (2011). Investors' Decision Making Process and Pattern of Investments - A Study of Individual Investors in Coimbatore. SIES Journal of Management, VII (2), 1-12.

[11] Prabhu \& Vechalekar (2013), "Perception of Indian Investor towards investment in mutual funds with special reference to MIP Funds", IOSR Journal of Economics and Finance (IOSRJEF), e-ISSN: 2321-5933, p-ISSN: 2321-5925, pp. 66-74.

[12] Purandare, J., \& Mehra, G. (2010), “Indian Mutual Fund Industry - Towards 2015: Sustaining Inclusive Growth - Evolving Business Models. Mumbai: Confederation of Indian Industry and PwC".

[13] Raman \& Budhiraja (2015), “An Empirical Study of Investment Pattern of Retail Investors in Mutual Funds", GCMRM 2015, MDI, Gurgaon, pp. 1-13.

[14] Shah, V., Zanwar, P., \& Deshmukh, P. (2011). Stages in Life Cycle and Investment Pattern of Rural Invesotrs - A Case Study. BVIMR Management Edge , IV (2), 48-59.

[15] Shollapur, M. R., \& Kuchanur, A. B. (2008). Identifying Perceptions and Perceptual Gaps: A Study of Individual Investors in Selected Investment Avenues. The Icfai University Journal of Behavioral Finance, V(2), 47-64.

[16] Singh and Jha (2009), "An empirical study on awareness \& acceptability of mutual fund", 4955, Regional Student's Conference, ICWAI.

[17] Singh, Binod Kumar (2012), “A study on investors' attitude towards mutual funds as an investment option", International Journal of Research in Management, ISSN 2249-5908, Issue2, Vol. 2, pp. 61-70.

[18] Sireesha, P. B., \& Laxmi, C. S. (2013). Impact of Demographics on Select Investment Avenues: A Case Study of Twin Cities of Hyderabad and Secunderabad, India. International Journal of Marketing, Financial Services \& Management Research, II (6), 48-55.

[19] Velmurugan et. Al. (2015), “An Empirical Analysis On Perception of Investors' Towards Various Investment Avenues", Mediterranean Journal of Social Sciences, MCSER Publishing, Rome-Italy, ISSN 2039-2117 (online), ISSN 2039-9340 (print), Vol 6 No 4, pp. 427-435.

[20] Vyas, Ravi (2012), "Mutual Fund Investor's Behavior and Perception In Indore City", Research world- -Journal of Arts, Science \& Commerce, E-ISSN 2229-4686, ISSN 22314172, Vol.- III, Issue-3(1), pp. 67-75. 